\title{
The shell middens of Las Bela coast and the Indus delta (Arabian Sea, Pakistan)
}

The surveys carried out along the coast of Las Bela (Balochistan) and the Indus delta (Sindh), have shown that these two regions were inhabited since the end of the eighth millennium BP. The discovery of shell middens along the shores of Daun Bay and Lake Siranda (Las Bela), have radically changed our view of the prehistory of this territory. The surveys conducted in the Indus delta have revealed that all the rocky outcrops rising from the alluvium are covered with chipped stone artefacts and marine and mangrove shells, which were radiocarbon dated between the seventh and fourth millennium BP, showing that all the outcrops above were islands at least until Hellenistic times. The radiocarbon results obtained from a few shell samples indicate that some of these islands had already been settled at the beginning of the seventh millennium BP, suggesting that seafaring was already practised along the northern Arabian Sea coast at least since the beginning of the Neolithic.

Keywords: Balochistan, Las Bela, Indus delta, shell middens, radiocarbon chronology, seafaring

\section{Introduction}

The purpose of this paper is to present the preliminary results of the discoveries made by the Italian Archaeological Mission along the coast of Las Bela (Balochistan), and the Indus delta (Lower Sindh) in 2000-2012. Earlier researches conducted in the 1970s in the same regions by Professor A.R. Khan, led to the recovery of an impressive number of prehistoric sites, many of which were attributed to the Mesolithic (Khan 1979a; Biagi 2003-2004). In one of his papers A.R. Khan reports the presence of shell scatters along the southernmost fringes of the Kirthar range, although never associated with archaeological materials (Khan 1979a: 18).

\section{The surveys}

A visit paid to the bay of Daun, some $13 \mathrm{~km}$ south of Gadani promontory, in January 2000 led to the discovery of the first shell middens of Las Bela coast. More middens were found in 2004 and 2008 during systematic surveys carried out along the shores of the same bay, and the marine terrace just south of it (Biagi 2004, 2011; Biagi \& Franco 2008) (Figs 1, 3/1).

\section{Paolo Biagi}

Asian and North African Studies, Ca' Foscari University, Ca' Cappello, San Polo 2035, I-30125, Venice, Italy

e-mail: pavelius@unive.it
Until then very little was known of the prehistory of Las Bela coast (Khan 1979b), given that most of the researches had been conducted in the territories of the inte-

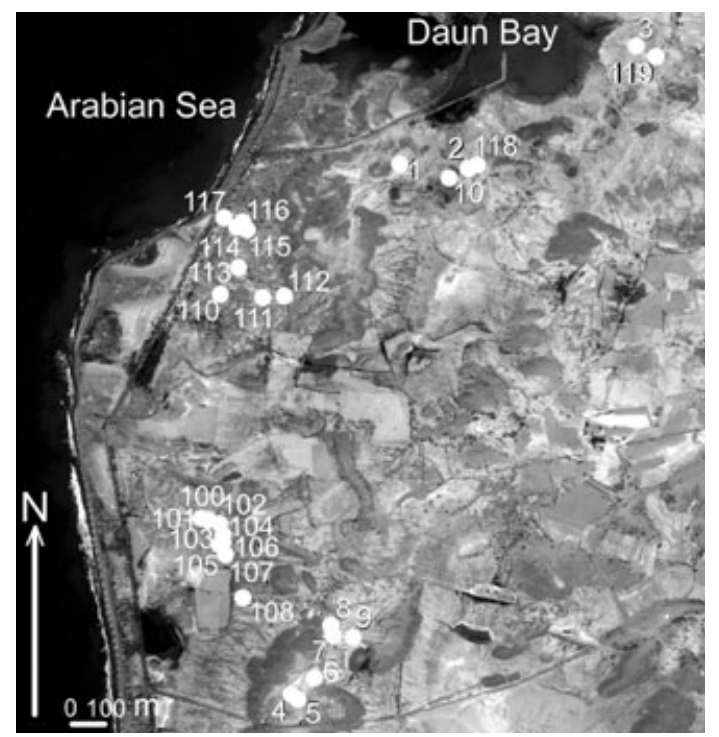

Fig. 1 .

Distribution map of the shell middens discovered around the Bay of Daun (after Biagi 2011: pl. 4). 
rior (Stein 1943; Raikes \& Dyson 1961; Khan 1964; Raikes 1968; de Cardi 1983; Franke-Vogt 1999). A.R. Khan (1979a: 5) had already reported the presence of prehistoric finds near Kunari Nallah, between Gadani and Phuari headlands, both rich in good-quality flint sources, which were exploited at least since the beginning of the Holocene (Khan 1979a: 12; Naseem, Sheikh \& Qadeeruddin 19961997: fig. 1; Biagi 2003-2004).

Much worse was our knowledge of the prehistory of Lake Siranda (Las Bela), with the exception of a report written by Aurel Stein regarding his expedition aimed at the definition of the route followed by Alexander the Great across the country of the Oreitai, an ethnic group culturally similar to the Ichthyophagi (Longo 1987: 12). In his paper he describes the place where the Macedonian army probably camped, close to 'a water not large', possibly the eastern shore of Lake Siranda (Stein 1943: 214).

Balakot is a large mound settled during the Chalcolithic and Bronze Age (Dales 1974, 1979, 1981), radiocarbon dated, from charcoal, between $3890 \pm 100$ (HAR-1993) and $5200 \pm 135$ uncal BP (UCLA-1923A) (Possehl 1988: 171-172; Shaffer 1986: 74). The study of the faunal remains recovered from this settlement showed the presence of many fragments of Terebralia palustris gastropods, suggesting the exploitation of a mangrove environment located close to the site (Meadow 1979: 296).

Scatters of T. palustris shells are reported also by R.E. Snead (1966: 60) from the central-eastern shore of Lake Siranda, at present a seasonal basin surrounded by sand dunes on its western side (Snead 1967; 1969: 33-35; Snead \& Frishman 1968). The lake, alimented mainly by summer monsoon rains, also receives water from the

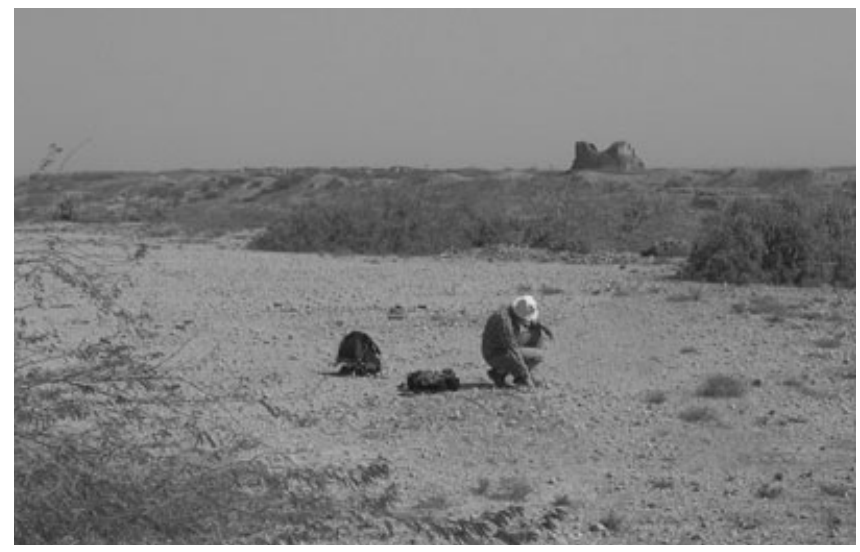

Fig. 2.

Makli Hills: site KKT 2 near Kalan Kot (in background) (photograph P. Biagi).
Watto and Windar (?) rivers. Many authors consider it a playa remnant of Miani Hor that 'functioned as a tidal lagoon in the not-too-distant past' (Snead 1966: 60).

The surveys in the Indus delta started in 2008, following the discovery of an oyster-shell scatter along the southern edge of the Tharro Hills near Gujo (Piggott 1950), radiocarbon dated to $6910 \pm 60$ uncal BP (GrN-32119) (Biagi \& Franco 2008; Biagi 2011: pl. 6) (Fig. 3/3).

The study of the Indus delta is of basic importance for understanding the changes that took place along the northern coast of the Arabian Sea in prehistoric (Flam 1984, 1987) and historic times (Eggermont 1975), and the depositional processes that led to the formation of the presentday Indus alluvial plain (Tremenheere 1867; Haigh 1894; Wilhelmy 1968; Harvey \& Schumm 1999; Prins et al. 2000; Giosan et al. 2006).

In his seminal volume on the geology of western Sindh, W.T. Blandford (1880: 154) reports the presence of several rocky outcrops rising from the Indus alluvium, which were all surveyed between 2008 and 2011. Surveys were also carried out on the Makli Hills, where scatters of mangrove shells, sometimes associated with flint artefacts, were recovered and radiocarbon dated (Figs 2, 3/4). The absolute results from the above sites point to the importance of the above-mentioned outcrops for the earliest peopling of the northern Arabian Sea coastal zone (Biagi 2009; 2011: table 1).

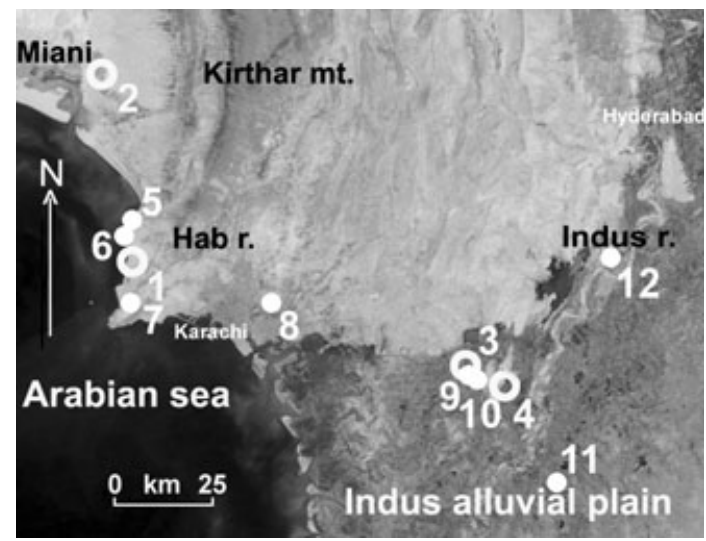

Fig. 3 .

Distribution map of the sites radiocarbon dated from mangrove and marine shells along the coast of Las Bela and in the Indus river delta. Eighth- and seventh-millennium uncal BP sites (circles): 1. Daun; 2. Lake Siranda; 3. Tharro Hills; 4. Makli Hills (see also Table 1). Other radiocarbon dated sites (dots): 5. Gadani; 6. Phuari; 7. Sonari; 8. Mulri Hills; 9. Beri; 10. Jabal Shah Husain; 11. Oban Shah; 12. Kot Raja Manjera (for details see Biagi 2011: table 1) (drawing P. Biagi). 
Table 1. Eighth- and seventh-millennium uncal BP and cal BC dates from the shell middens of Las Bela (Balochistan) and Lower Sindh: Lake Siranda (SRN), Daun, Tharro Hills (THR 2) and Makli Hills (KKT 2). Calibration applied a $\Delta$ R of $229 \pm 27$ years (Dutta, Bushan \& Somayajulu 2001; Reimer \& Reimer 2001).

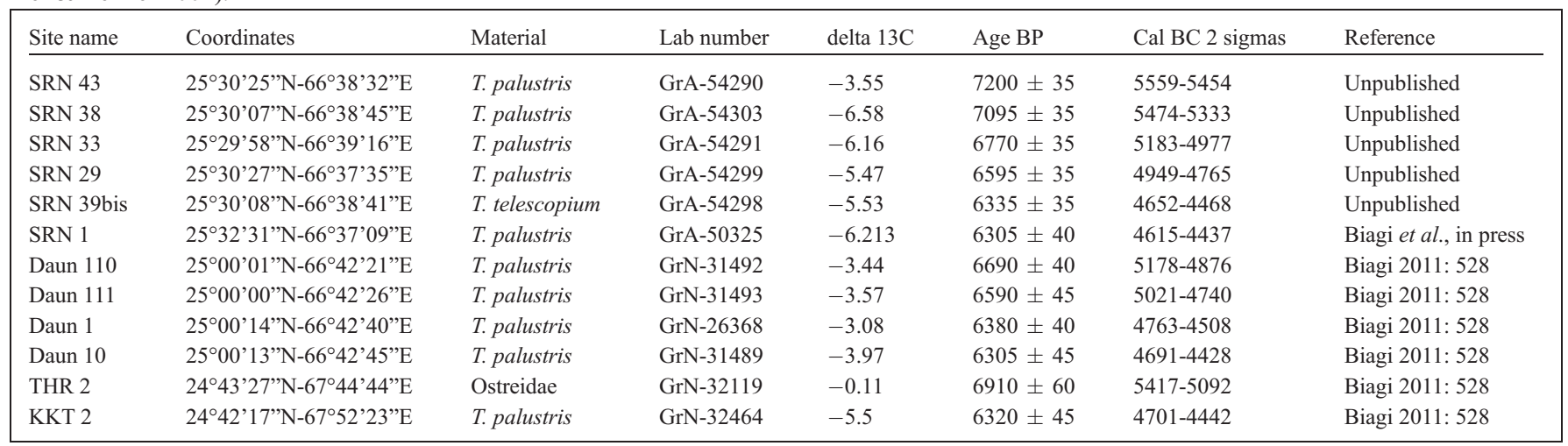

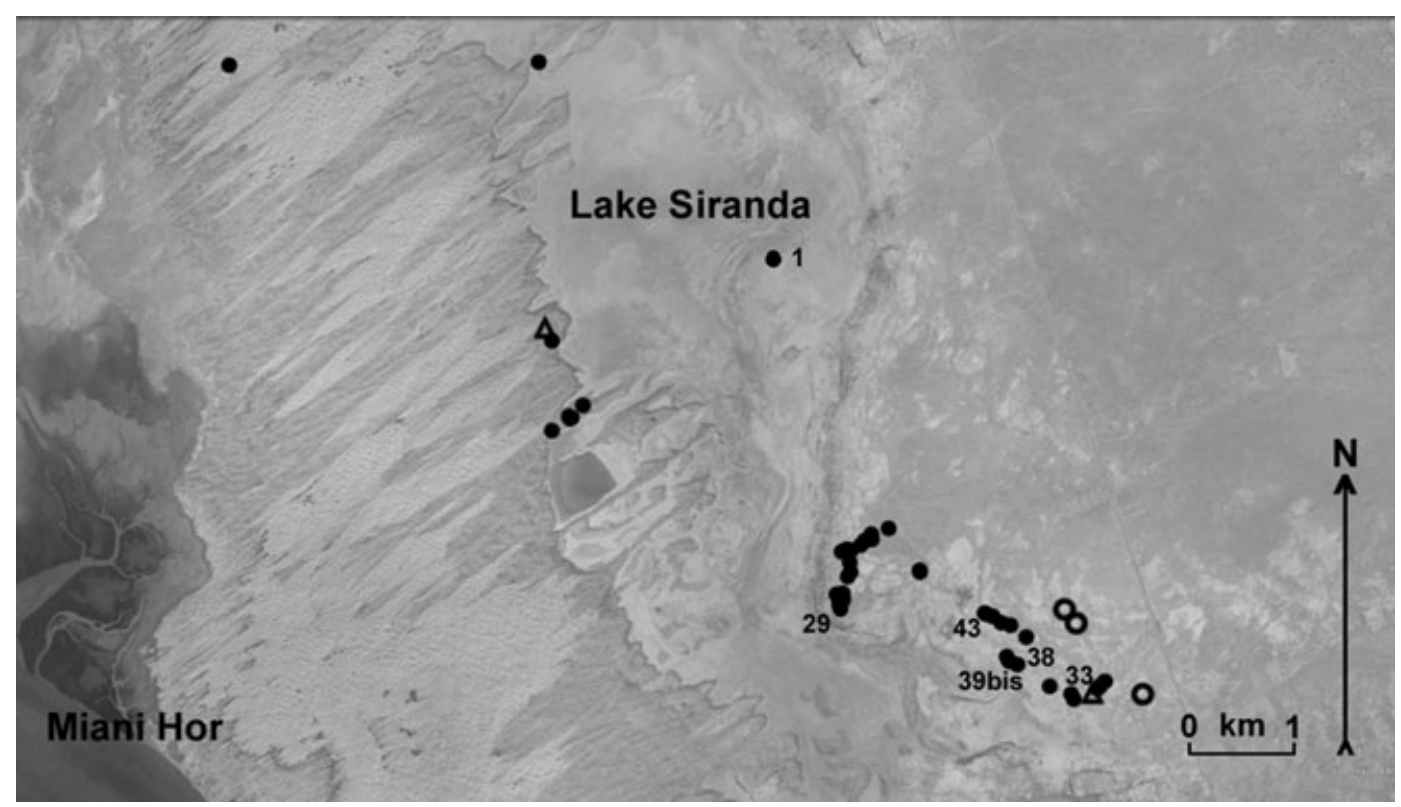

Fig. 4.

Lake Siranda: distribution map of the sites discovered in 2011-2012, with the eighth- and seventh-millennium BP AMS-dated shell middens indicated by numbers (see also Table 1). Key: dots: shell middens; circles: lithic scatters; triangles: Islamic graveyards (courtesy C. Franco).

\section{Discussion}

The discovery of the above-mentioned prehistoric sites raises a number of questions:

1. The presence of shell middens radiocarbon dated to the eighth and seventh millennia BP (Fig. 3 \& Table 1). It is well known that the coasts of the Arabian Peninsula and the Persian/Arabian Gulf were first settled between the end of the eighth and the early seventh millennium uncal BP, when the sea level stabilised slightly after the beginning of the Atlantic climatic period (Lambeck
1996; Biagi 2008a; Boivin \& Fuller 2009). The above situation can be compared to that evidenced by the discovery of prehistoric sites along the coasts of Lower Sindh and Las Bela. In Lower Sind the seventh-millennium uncal BP sites located on the rocky outcrops rising from the Indus plain, show that seafaring was already practised along the northern coastline of the Arabian Sea around the beginning of the Neolithic, as the finds from site $\mathrm{H} 3$ in Kuwait have also shown for the Persian/Arabian Gulf (Carter 2008). The shell mid- 


\section{P. BIAGI}

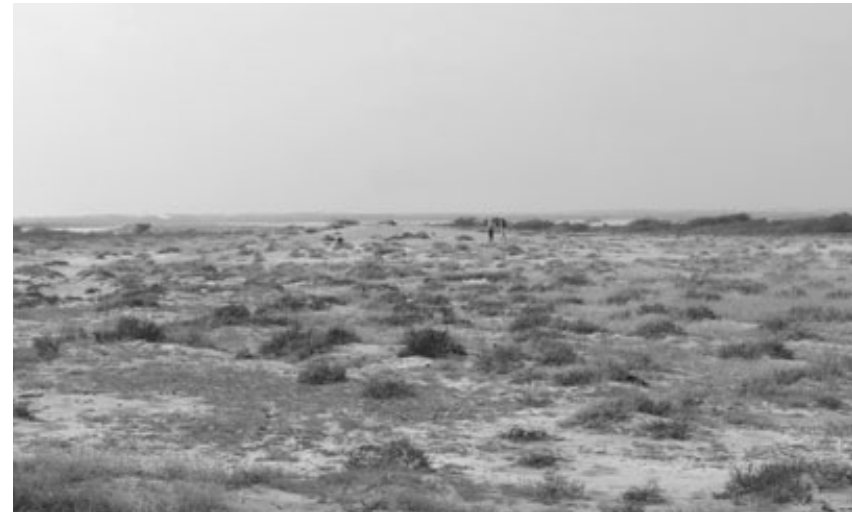

Fig. 5 .

Lake Siranda: shell midden SRN29, in the centre of the image, located along the central-eastern shore of the basin (photograph P. Biagi).

dens discovered along the shores of Lake Siranda (Figs $3 / 2,4 \& 5$ ) demonstrate that, at least from the end of the eighth and throughout the seventh and sixth millennia BP, Siranda was a lagoon of the Arabian Sea partly surrounded by mangroves (Biagi, Girod \& Nisbet, in press). Together with those recorded around the Bay of Daun, these middens contribute to the understanding of the environmental changes that took place in the region, and the effect of the human impact on the landscape between the Neolithic and the Bronze Age. This pattern can be compared to that already known along the eastern coasts of the Arabian Peninsula, in Oman for instance, and the Persian/Arabian Gulf (Lézine et al. 2002; Berger et al. 2005; Sanlaville \& Dalongeville 2005; Charpentier 2008).

2. The scarcity of Neolithic sites all over Pakistan has been discussed recently by Petrie et al. (2010). The discovery of the above-mentioned shell middens shows that Neolithic settlements undoubtedly exist in the area, most probably within one day's walk from the Arabian Sea coasts of Lower Sindh and Las Bela, and that the present-day picture is mainly due to the absence of accurate surveys aimed at their recovery.

3. The presence of trapezoidal geometrics and lunates from the Daun and Siranda shell middens, obtained from micro-bladelets of Gadani and Balochistan flint (Malkani 2011: 275) (Fig. 6). As regards the trapezes, these tools are typologically different from those already known from the Mesolithic sites of both the Mulri Hills (Karachi) and the Thar Desert of Upper Sindh (Biagi 2003-2004; Biagi 2008b), and also the aceramic Neolithic layers of Mehrgarh (Lechevallier 2003; Costantini 2007-2008; Jarrige 2007-2008),
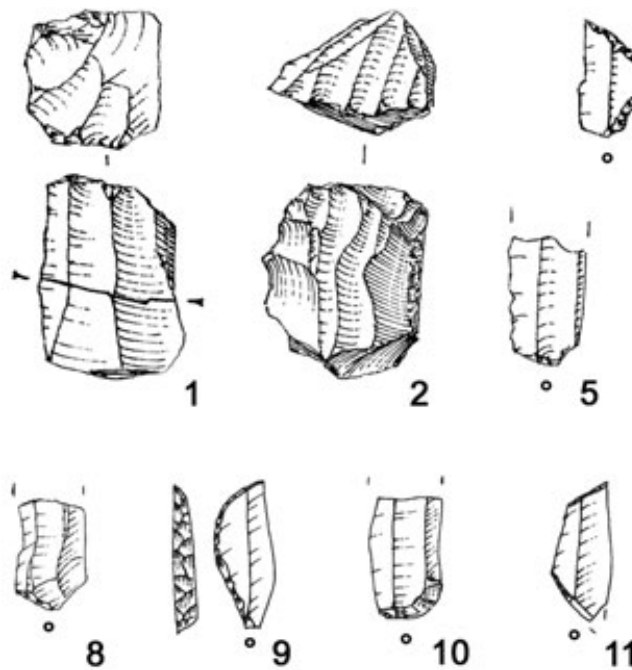

3
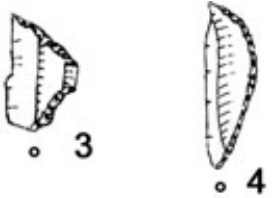

8
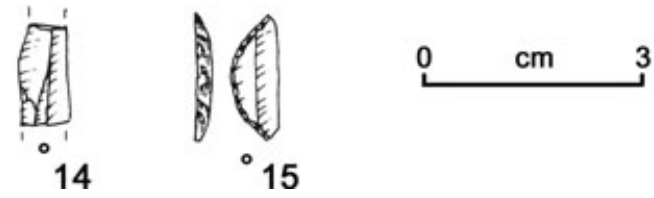

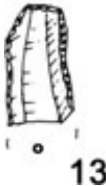

13
Chipped stone artefacts from Daun and Lake Siranda shell middens. 1. and 2. prismatic bladelet cores; 3, 11, and 12. Isosceles trapeze; 4, 9 and 15. lunates; 5-8, 10 and 14. narrow micro-bladelets; 13. backed bladelet and truncation. Provenance: 1, 3, 6 and 7. Daun 1; 2, 4 and 5. Daun 10; 8. SRN 38; 9. SRN 40; 10-12. SRN 39bis; 13-15. SRN 42 (nos. 3, 5, 8-15 are of Gadani red flint) (drawings P. Biagi, inking G. Almerigogna and E. Starnini).

which closely resemble Central Asian horned types (Brunet 2012: 320).

These are just a few of the problems raised by the recent discoveries made along the northern coast of the Arabian Sea, a territory of fundamental importance for the understanding of the prehistoric peopling of this part of the Indian Subcontinent and its neighbouring regions.

\section{Acknowledgements}

The author is very grateful to Professors M.K. Badini and A.H. Bouk (Department of Computer Science, Quetta University), Mir Atta M. Talpur and Mir Ahmed F. Talpur (Mirpur Khas), Dr M. Spataro (British Museum, London), Professor R. Nisbet and Dr C. Franco (Ca' Foscari University, Venice), Mr A. Girod (Italian Malacological Society) who took part in the Pakistan coastal surveys and Mr T. Fantuzzi (Ca' Foscari University, Venice) for the calibration of the radiocarbon dates. Thanks are also due to the Italian Ministry of Foreign Affairs (Rome), the CeVeSCO (Ca' Foscari University, Venice), the Ca' Foscari University Archaeology Research Fund (Venice) and the EURAL Gnutti (Rovato, Brescia) for sponsoring the Las Bela research project currently underway. 


\section{SHELL MIDDENS OF LAS BELA COAST AND THE INDUS DELTA}

\section{References}

Berger, J-F., Cleuziou, S., Davtian, G., Cattani, M., et al. 2005. Évolution

paléogéographique du Ja'alan (Oman) à

l'Holocène moyen: Impact sur l'évolution des paléomilieux littoraux et les stratégies d'adaptation des communautés humaines. Paléorient 31/1: 46-63.

Biagi, P. 2003-2004. The Mesolithic Settlement of Sindh (Pakistan): A Preliminary Assessment. Praehistoria 4-5: 195-220.

Biagi, P. 2004. New radiocarbon dates for the prehistory of the Arabian Sea coasts of Lower Sindh and Las Bela in Balochistan. Rivista di Archeologia 28: 5-16.

Biagi, P. 2008a. The shell-middens of the Arabian Sea and Gulf: Maritime connections in the seventh millennium BP? Pages 7-18 in Al-Ansary, A.R., AlMuaikel, K.I. \& Alsharek, M. (eds.), The City in the Arab World in Light of Archaeological Discoveries: Evolution and Development (Riyadh, Abdul Rahman Al-Sudairy Foundation).

Biagi, P. 2008b. New Discoveries of Mesolithic Sites in the Thar Desert (Upper Sindh, Pakistan). Pages 78-85 in Olijdam, E. \& Spoor, R.H. (eds.), Intercultural Relations between South and Southwest Asia. Studies in Commemoration of E.C.L. During Caspers (1934-1996) (Oxford, BAR International Series 1826).

Biagi, P. 2009. Archaeological Surveys in Lower Sindh: Preliminary Results of the 2009 Season. Journal of Asian Civilizations 33: 1-42.

Biagi, P. 2011. Changing the prehistory of Sindh and Las Bela coast: twenty-five years of Italian contribution. World Archaeology 43/4: 523-537.

Biagi, P., Girod, A. \& Nisbet, R. in press. Prehistoric shell middens, seascapes and landscapes at Lake Siranda (Las Bela, Balochistan, Pakistan): A review. In Tripathi, A. (ed.), Recent Researches in Archaeology, Art, History and Culture of Northeast India. Professor J.B. Bhattacharjee Felicitation Volume (Assam University, Department of History).

Blandford, W.T. 1880. The Geology of Western Sind. Memoirs of the Geological Survey of India 17: 1-120.

Boivin, N. \& Fuller, D. 2009. Shell Middens, Ships and Seeds: Exploring Coastal Subsistence, Maritime Trade and Dispersal of Domesticates in and Around the Ancient Arabian Peninsula. Journal of World Prehistory 22: 113-180.

Brunet, F. 2012. The technique of Pressure Knapping in Central Asia: Innovation or Diffusion? Pages 307-328 in Desrosiers, P.M. (ed.), The Emergence of Pressure Blade Making from Origin to Modern Experimentation (New York/London, Springer).

Carter, R. 2008. Excavations and Ubaid-Period Boat Remains at H3, Al-Sabiyah (Kuwait). Pages 92-102 in Olijdam, E. \& Spoor, R.H. (eds.), Intercultural Relations between South and Southwest Asia. Studies in Commemoration of E.C.L. During Caspers (1934-1996) (Oxford, BAR International Series 1826).

Charpentier, M. 2008. Hunter-gatherers of the 'empty quarter of the early Holocene' to the last Neolithic societies: chronology of the late prehistory of south-eastern Arabia. Proceedings of the Seminar for Arabian Studies 26: 1-12.

Costantini, L. 2007-2008. The First Farmers in Western Pakistan: The Evidence of the Neolithic Agro-pastoral Settlement of Mehrgarh. Prāgdhārā 18: $167-178$.

Dales, G.F. 1974. Excavations at Balakot, Pakistan, 1973. Journal of Field Archaeology 1: 3-22.

Dales, G.F. 1979. The Balakot Project: Summary of Four Years Excavations in Pakistan. Pages 241-274 in Taddei, M. (ed.), South Asian Archaeology 1977. (Seminario di Studi Asiatici, Series Minor VI) (Naples, Istituto Universitario Orientale).

Dales, G.F. 1981. Reflections on five years of Excavations at Balakot. Pages 25-32 in Dani, A.H. (ed.), Indus Civilisation: New Perspectives (Islamabad, Quaid-I-Azam University).

de Cardi, B. 1983. Archaeological Surveys in Baluchistan, 1948 and 1957. London: Institute of Archaeology Occasional Publication No. 8.

Dutta, K., Bhushan, R. \& Somayajulu, B.L.K. 2001. $\Delta \mathrm{R}$ Correction Values for the Northern Indian Ocean. Radiocarbon 43/ 2A: 483-488.

Eggermont, P.H.L. 1975. Alexander's campaigns in Sind and Balochistan and the siege of the Brahmin town of Harmatelia. (Orientalia Lovaniensa
Analecta, 3). Leuven: Leuven University Press.

Flam, L. 1984. The Palaeogeography and Prehistoric Settlement Patterns of the Lower Indus Valley, Sind, Pakistan. Pages 77-82 in Kennedy, K.A.R. \& Possehl, G.L. (eds.), Studies in the Archaeology and Palaeoanthropology of South Asia (New Delhi/Bombay, Oxford \& IBH Publishing Co).

Flam, L. 1987. Recent Explorations in Sind: Paleogeography, Regional Ecology, and Prehistoric Settlement Patterns (ca. 4000 2000 B.C.). Pages 65-89 in Jacobson, J. (ed.), Studies in the Archaeology of India and Pakistan (Warminster, Aris \& Phillips).

Franke-Vogt, U. 1999. A Survey of Archaeological Sites in Sind Kohistan and the Greater Hab Valley. Report on a Survey carried out between January 6th and 18th and March 4th to 11th, 1999, for LASMO Oil Pakistan Lmt, Berlin: Institute of Near Eastern Archaeology.

Giosan, L., Constantinescu, S., Clift, P.D., Tabrez, A.R., et al. 2006. Recent morphodynamics of the Indus delta shore and shelf. Continental Shelf Research 26: 1668-1684.

Haigh, M.R. 1894. The Indus Delta Country. A memoir chiefly on its ancient geography and history, London: Kegan Paul, Trench, Trübner \& Co.

Harvey, M.D. \& Schumm, S.A. 1999. Indus River Dynamics and the Abandonment of Mohenjo Daro. Pages 332-348 in Meadows, A., Meadows, P.S. (eds.), The Indus River: Biodiversity, Resources, Humankind (Karachi, University Press).

Jarrige, J-F. 2007-2008. Mehrgarh Neolithic. Prāgdhārā 18: 135-154.

Khan, F.A. 1964. Las Bela and S.W. Sind Expedition: 1959-60. Pakistan Archaeology 1: 32-34.

Khan, A.R. 1979a. Ancient Settlements in Karachi Region. Pages 1-24 in Khan, A.R. (ed.), Studies in Geomorphology and Prehistory of Sind. Grassroots Special Issue 3/2: 1-24.

Khan, A.R. 1979b. New Archaeological Sites in Las Bela - A Neolithic Settlement Discovered. Pages 69-82 in Khan, A.R. (ed.), Studies in Geomorphology and Prehistory of Sind. Grassroots Special Issue 3/2: 62-79. 


\section{P. BIAGI}

Lambeck, K. 1996. Shoreline reconstructions of the Persian Gulf since the last glacial maximum. Earth and Planetary Science Letters 142: 43-57.

Lechevallier, M. 2003. L'industrie lithique de Mehrgarh fouilles 1974-1985. Paris: Éditions Recherche sur les Civilisations.

Lézine, A-M., Saliège, J-F., Mathieu, R., Tagliatela, T-L., et al. 2002. Mangroves of Oman during the Late Holocene: climatic implications and impact of human settlements. Vegetation History and Archaeobotany 11: 221-232.

Longo, O. 1987. A Trip Among the Fish Eaters. Newsletter of Baluchistan Studies 4: 11-18.

Malkani, M.S. 2011. Stratigraphy, Mineral Potential, Geological History and Paleobiogeography of Balochistan Province, Pakistan. Sindh University Research Journal (Science Series) 43/2: 269-290.

Meadow, R.H. 1979. Prehistoric Subsistence at Balakot: Initial Considerations on the Faunal remains. Pages 275-315 in Taddei, M. (ed.), South Asian Archaeology 1977. (Seminario di Studi Asiatici, Series Minor VI) (Naples, Istituto Universitario Orientale).

Naseem, S., Sheikh, S.A. \& Qadeeruddin, M. 1996-1997. Geochemistry and Tectonic Setting of Gadani-Phurai Segment of Bela Ophiolithes, Balochistan, Pakistan.

Journal of Karachi University, Earth Sciences 9: 127-144.
Petrie, C.A., Khan, F., Knox, R., Thomas, K. \& Morris, J. 2010. The investigation of early villages in the hills and on the plains of western South Asia. Pages 7-28 in Petrie C.A. (ed.), Sheri Khan Tarakai and early village life in the borderlands of north-west Pakistan. (Oxford/Oakville, Oxbow Books).

Piggott, S. 1950. Prehistoric India to 1000 B.C. Harmondsworth: Penguin Books.

Possehl, G.L. 1988. Radiocarbon Dates from South Asia. Man and Environment XII: 169-196.

Prins, M.A., Postma, G., Cleveringa, J., Cramps, A. \& Kenyon, N.H. 2000. Controls on terrigenous sediment supply to the Arabian Sea During the Late Quaternary: The Indus Fan. Marine Geology 169: 327-349.

Raikes, R.L. 1968. Archaeological explorations in southern Jhalawan, and Las Bela (Pakistan). Origini 2: 103-171.

Raikes, R.L. \& Dyson, R.H. 1961. The Prehistoric Climate of Baluchistan and the Indus Valley. American Anthropologist 63: 265-281.

Reimer, P.J. \& Reimer, R.W. 2001. A Marine reservoir correction database and on-line interface. Radiocarbon 43(2A): 461-463.

Sanlaville, P. \& Dalongeville, R. 2005. L'évolution des espaces littoraux du Golfe Persique et du Golfe d'Oman depuis la phase finale de la transgression post-glaciaire. Paléorient 31/1: 9-26.
Shaffer, J.G. 1986. The Archaeology of Baluchistan: A Review. Journal of Baluchistan Studies 3: 63-111.

Snead, R.E. 1966. Physical Geography Reconnaissance: Las Bela Costal Plain, West Pakistan. (Louisiana State University Studies Coastal Studies Series 13). Baton Rouge: Louisiana State University Press.

Snead, R.E. 1967. Recent morphological changes along the coast of West Pakistan. Annals of the Association of American Geographers 57/3: 550-565.

Snead, R.E. 1969. Physical Geography Reconnaissance: West Pakistan Coastal Zone. (University of New Mexico Publications in Geography 1). Albuquerque: Department of Geography, University of New Mexico.

Snead, R.E. \& Frishman, S.A. 1968. Origin of sands on the East Side of the Las Bela Valley, West Pakistan. Geological Society of America Bulletin 79: 16711676.

Stein, A. 1943. On Alexander's Route into Gedrosia: An Archaeological Tour in Las Bela. The Geographical Journal CII 5-6: 193-227.

Tremenheere, C.W. 1867. On the Lower Portion of the River Indus. Journal of the Royal Geographic Society of London 37: 68-91.

Wilhelmy, H. 1968. Indusdelta und Rann of Kutch. Erdkunde 22/3: 177-191. 